\title{
Ethnobotanical Uses of Some Plants of Bhattiyat Block in District Chamba, Himachal Pradesh (Western Himalaya)
}

\author{
Savita Rani and J.C. Rana
}

\section{Research}

\begin{abstract}
In this study an ethnobotanical survey of plant diversity was carried out at Bhattiyat block of District Chamba, Himachal Pradesh, India. The study was mainly focused on the medicinal plants used for treatment of various ailments/diseases by the nearby village inhabitants. The information was collected by questionnaire and consulting local elders. The present paper provides information on the indigenous therapeutic application and other traditional uses of 22 plant species that are commonly used by the natives of Bhattiyat block of District Chamba.
\end{abstract}

\section{Introduction}

District Chamba is situated in the northwestern end of the Himachal Pradesh between $32^{\circ} 11^{\prime} 30^{\prime \prime}-33^{\circ} 13^{\prime} 06^{\prime \prime} \mathrm{N}$ and $75^{\circ} 03^{\prime} 49^{\prime \prime}-77^{\circ} 03^{\prime} 30^{\prime \prime} \mathrm{E}$ and is surrounded by hill ranges. The geographical area of the district is $6528 \mathrm{~km}^{2}$, comprising $25 \%$ of total area of the state. The territory is wholly mountainous with altitudes ranging from 600 to $6400 \mathrm{~m}$. Chamba is a forested district with a total forest area of approximately $5030 \mathrm{~km}^{2}$. Nearly 2000 flowering plant species have been documented across District Chamba with floristic affinities from tropical-subtropical to temperate alpine (Singh \& Sharma 2006).

District Chamba is inhabited by two main tribal (rural) communities: Gaddis (migratory pastoralists) and Gujjar (nomadic tribe). These native people are the custodians of indigenous knowledge associated with their surrounding biological resources (Dutt et al. 2011). Aside from exploring floristic diversity and inventorying plant resources of the district (Sharma \& Singh 1990, 1997), documentation of traditional knowledge on the utilization of plants has been initiated by few workers. Dutt et al. (2011) provides the information on 70 species of medicinal and aro- matic plants from Bharmour block, and Singh and Banyal (2012) explored the Kalatop and Khajjiar area of District Chamba. The present study is an attempt to enhance such investigations.

\section{Materials and Methods}

In order to document the utilization of medicinal plants, a total of 10 field surveys were carried out in the area from July 2011 to July 2013 . The surveys were spread across seasons to get maximum information and also to crosscheck the information provided by the local informants during the earlier visits. Surveys were conducted among the Masas, Gaddi, Brahmin, Rajput, Gujjar, and Lohar communities residing in different localities of Bhattiyat block of District Chamba (Figure 1). During the initial surveys, friendly relations were developed with the village people. Information on medicinal plants was gathered in the local language (Chambali). Twenty vaidyas (local healers), 15 male and 5 female) were identified and interviewed during subsequent surveys. Structured questionnaires, interviews, and participatory observations were used to illicit information from the informants (Martin 1995, Reyes-Garcia et al. 2005). Information on local name, exact plant

\section{Correspondence}

Savita Rani and J.C. Rana, National Bureau of Plant Genetic Resources Regional Station, Phagli, Shimla, Himachal Pradesh - 171 004, INDIA.

savitarana3@gmail.com

Ethnobotany Research \& Applications 12:407-414 (2014)

\section{Published: 19 September 2014}




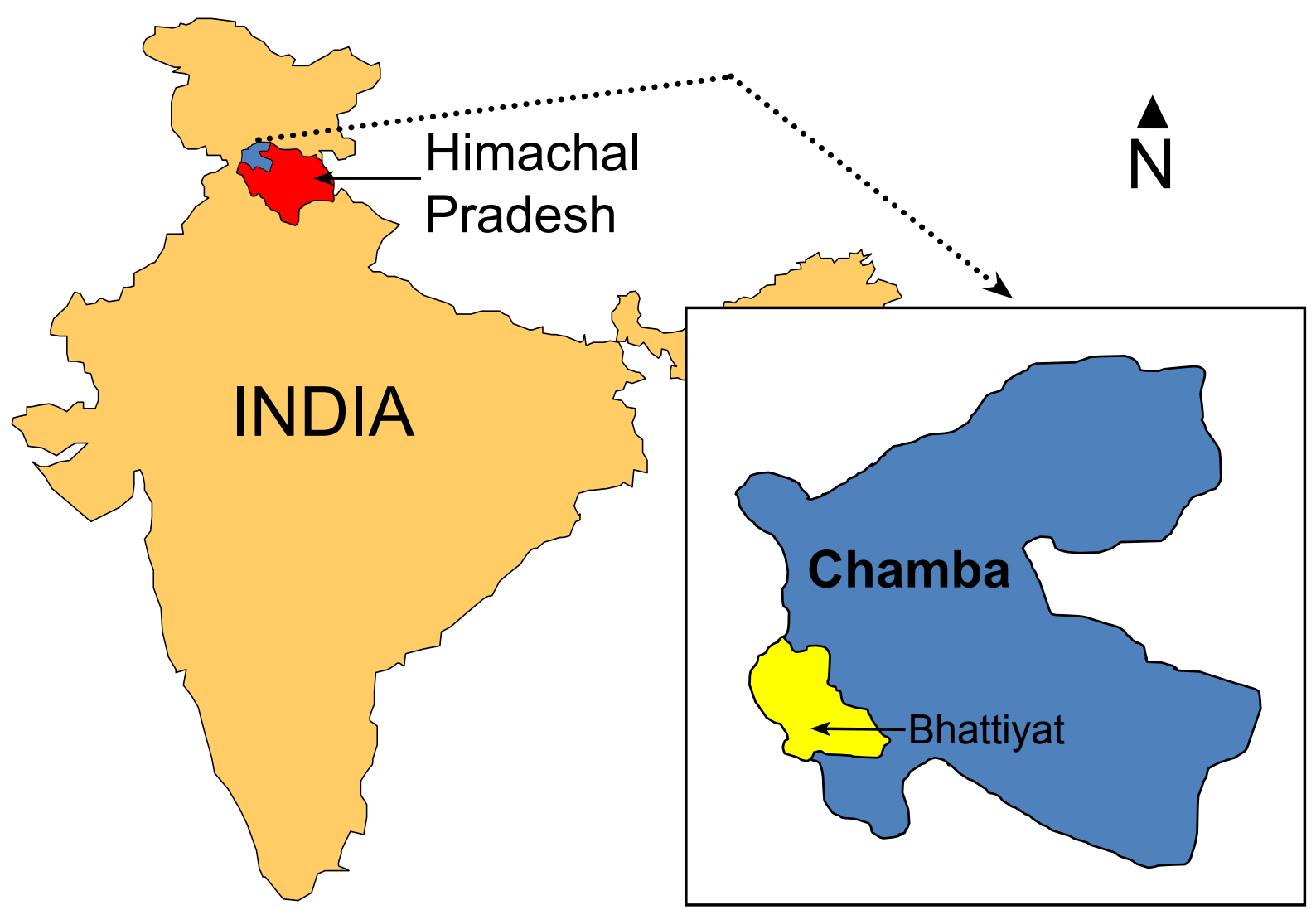

Figure 1. The study region of Bhattiyat block (yellow) of District Chamba (blue), Himachal Pradesh (red), India.

part used, and method of dosage of these plants was provided by informants. The identification of the plants was done with the help of various floras (Chowdhery \& Wadhwa 1984, Dhaliwal \& Sharma 1999, Hooker 1879, Kaur \& Sharma 2004, Singh \& Sharma 2006). The identifications were then confirmed by matching the plants with authenticated specimens available in the Herbaria of Forest Research Institute (DD), Dehradun, India, and Botanical Survey of India (Northern Regional Center) (BSD), Dehradun, India. Scientific names were verified and updated using The Plant List (2013) and Tropicos. org (2014). Voucher specimens have been deposited in the Herbarium, National Bureau of Plant Genetic Resources Regional Station, Phagli, Shimla, Himachal Pradesh, India.

\section{Results}

Twenty-two plant species were identified by residents of Bhattiyat block of District Chamba as having specific ethnomedicinal uses. These species are in 17 plant families with only Asteraceae and Lamiaceae having more than one reported species. Both native species and cultivated exotic species were reported. Results from the informant questionnaires are summarized in Table 1.

\section{Discussion}

Several species that were reported as useful for treating liver-related ailments have other documented ethnomedicinal or ethnobotanical uses. In addition to treating acute hepatitis, Allium sativum $\mathrm{L}$. is a common spicy flavoring agent that can be used for its antimicrobial, antithrombotic, hypolipidemic, antiarthritic, hypoglycemic, and antitumor properties (Thomson \& Ali 2003). Brahmi (Bacopa monnieri (L.) Wettst.) is commonly used in the treatment of anxiety, neurosis, mental fatigue, improving mental clarity, confidence, and memory recall and is a traditional ayurvedic treatment for epilepsy and asthma (Gohil \& Patel 2010). Cajanus cajan (L.) Millsp. is indicated in the relief of pain in traditional Chinese medicine and as a sedative (Ahsan et al. 2009). In southern parts of India, the leaves of Cajanus cajan (L.) Millsp. are commonly used for rearing silkworms; its green pods are used as a vegetable, and the husk, green leaves, and tops are used as fodder and green manure (Ambasta 2004).

Arnebia benthamii (Wall. ex G.Don) I.M.Johnst. is a highvalue Himalayan medicinal plant, ranking second in the 


\section{Rani \& Rana - Ethnobotanical Uses of Some Plants of Bhattiyat Block in District Chamba, Himachal Pradesh (Western Himalaya)}

Table 1. Plants reported as having ethnobotanical use by residents of Bhattiyat block of District Chamba, Himachal Pradesh, India. Parts used: bark (Ba), bud (Bu), flower (F), leaf (L), root $(R)$, seed (Se), stem (St).

\begin{tabular}{|c|c|c|c|c|}
\hline $\begin{array}{l}\text { Scientific name } \\
\text { [Family] } \\
\text { Acc. no. }\end{array}$ & $\begin{array}{l}\text { Local } \\
\text { name }\end{array}$ & Distribution & 量 d & Ethnobotanical use(s) \\
\hline $\begin{array}{l}\text { Allium sativum L. } \\
\text { [Amaryllidaceae] } \\
24491\end{array}$ & Lashun & Native to Asia & $\mathrm{F}$ & $\begin{array}{l}\text { A paste of } 5-6 \text { buds with } 20 \mathrm{~g} \text { fresh } \\
\text { leaves of Leucas aspera (Willd.) Link } \\
\text { mixed in a glass of warm water is pre- } \\
\text { scribed twice daily for } 5 \text { days with a } \\
\text { small ripe banana for acute hepatitis } \\
\text { associated with dyspepsia and loss of } \\
\text { appetite. }\end{array}$ \\
\hline $\begin{array}{l}\text { Alternanthera sessilis (L.) } \\
\text { R.Br. ex DC. } \\
\text { [Amaranthaceae] }\end{array}$ & Garundi & $\begin{array}{l}\text { Widespread in old } \\
\text { and new world trop- } \\
\text { ics and sub-tropics }\end{array}$ & $L$ & $\begin{array}{l}\text { Leaf decoction with a little salt is drunk } \\
\text { to check vomiting of blood. }\end{array}$ \\
\hline $\begin{array}{l}\text { Aplotaxis auriculata DC. } \\
\text { [Asteraceae] }\end{array}$ & Kut & Native to Himalayas & $L$ & $\begin{array}{l}\text { Leaf paste is externally applied for ve- } \\
\text { nereal diseases. }\end{array}$ \\
\hline $\begin{array}{l}\text { Arnebia benthamii (Wall. } \\
\text { ex G.Don) I.M.Johnst. } \\
\text { [Boraginaceae] } \\
25501\end{array}$ & Rattanjot & $\begin{array}{l}\text { Mostly occurring in } \\
\text { the alpine and sub- } \\
\text { alpine Himalayas at } \\
3000-3900 \mathrm{~m}\end{array}$ & $\mathrm{R}$ & $\begin{array}{l}\text { Dried roots are immersed in mustard oil } \\
\text { and kept for } 1-2 \text { weeks. When the color } \\
\text { changes to reddish pink, it is then ap- } \\
\text { plied to the scalp for prevention of hair } \\
\text { loss and removal of dandruff. }\end{array}$ \\
\hline $\begin{array}{l}\text { Bacopa monnieri (L.) Wettst. } \\
\text { [Plantaginaceae] } \\
26409\end{array}$ & Brami & $\begin{array}{l}\text { Widespread in trop- } \\
\text { ics and sub-tropics } \\
\text { below } 1100 \mathrm{~m}\end{array}$ & $\mathrm{~L}, \mathrm{St}$ & $\begin{array}{l}\text { About } 5 \mathrm{~g} \text { fresh juice of the leaves } \\
\text { boiled with ghee and } 2.5 \mathrm{~g} \text { root of Aplo- } \\
\text { taxis auriculata DC. and honey is pre- } \\
\text { scribed internally for bilious disorders. } \\
\text { Paste of the shoot along with shoots of } \\
\text { Centella asiatica (L.) Urb. and Alternan- } \\
\text { thera sessilis (L.) R.Br. ex DC. in equal } \\
\text { parts (10-15 g each) is given twice dai- } \\
\text { ly on an empty stomach for both chron- } \\
\text { ic and acute liver disorders associated } \\
\text { with hepatomegaly. }\end{array}$ \\
\hline $\begin{array}{l}\text { Bergenia pacumbis } \\
\text { (Buch.-Ham. ex D.Don) } \\
\text { C.Y.Wu \& J.T.Pan } \\
\text { [Saxifragaceae] } \\
25502\end{array}$ & Shaprotri & $\begin{array}{l}\text { From Kashmir to } \\
\text { Bhutan at 2100- } \\
3000 \text { m and Khasia } \\
\text { hills at } 4000 \text { m (Kir- } \\
\text { tikar \& Basu 1983, } \\
\text { Pandey 1988) }\end{array}$ & $\mathrm{L}$ & $\begin{array}{l}\text { Dried leaves are ground and inhaled to } \\
\text { recover from heavy sneezing. Leaves } \\
\text { are used as pattar (a type of gate) dur- } \\
\text { ing marriage ceremonies. }\end{array}$ \\
\hline $\begin{array}{l}\text { Cajanus cajan (L.) Millsp. } \\
\text { [Fabaceae] } \\
26419\end{array}$ & $\begin{array}{l}\text { Arehar } \\
\text { chana }\end{array}$ & $\begin{array}{l}\text { Native of tropical } \\
\text { Africa; widely culti- } \\
\text { vated }\end{array}$ & $\mathrm{L}, \mathrm{Se}$ & $\begin{array}{l}\text { Leaf juice or a young leaf decoction is } \\
\text { given with sugar for jaundice (regularly } \\
\text { in morning) for about } 1 \text { month. Seeds } \\
\text { are useful for treating vitiated condi- } \\
\text { tions of the pitta. Juice of } 2-4 \text { seeds } \\
\text { is given twice daily for } 4-5 \text { days for } \\
\text { acute viral hepatitis. }\end{array}$ \\
\hline $\begin{array}{l}\text { Centella asiatica (L.) Urb. } \\
\text { [Apiaceae] }\end{array}$ & $\begin{array}{l}\text { Brahma } \\
\text { manduki }\end{array}$ & $\begin{array}{l}\text { Tropical America, } \\
\text { Africa, India, W. } \\
\text { Pakistan, China } \\
\text { Japan, and Pacific } \\
\text { Islands }\end{array}$ & $\mathrm{L}$ & $\begin{array}{l}\text { Leaf extract is taken once daily to treat } \\
\text { any type of weakness. }\end{array}$ \\
\hline
\end{tabular}


Table 1. Continued.

\begin{tabular}{|c|c|c|c|c|}
\hline $\begin{array}{l}\text { Scientific name } \\
\text { [Family] } \\
\text { Acc. no. }\end{array}$ & $\begin{array}{l}\text { Local } \\
\text { name }\end{array}$ & Distribution & 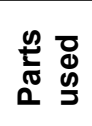 & Ethnobotanical use(s) \\
\hline $\begin{array}{l}\text { Cinnamomum verum } \\
\text { J.Presl. } \\
\text { [Lauraceae] }\end{array}$ & Dalchini & $\begin{array}{l}\text { Native to Sri Lanka; } \\
\text { cutlivated in many } \\
\text { Asian countries }\end{array}$ & $\mathrm{Ba}$ & $\begin{array}{l}\text { Cinnamon from dried bark is used to } \\
\text { treat stomachache. }\end{array}$ \\
\hline $\begin{array}{l}\text { Clematis barbellata } \\
\text { Edgew. } \\
\text { [Ranunculaceae] } \\
25503\end{array}$ & Bhtaani & $\begin{array}{l}\text { From Kashmir east- } \\
\text { ward to Nepal }\end{array}$ & L & $\begin{array}{l}\text { Leaves are crushed either with water } \\
\text { or cow urine, and the paste is applied } \\
\text { on pimple and boil eruptions to treat the } \\
\text { infected part. }\end{array}$ \\
\hline $\begin{array}{l}\text { Foeniculum vulgare Mill. } \\
\text { [Apiaceae] }\end{array}$ & Mithisaunf & $\begin{array}{l}\text { Native to the Medi- } \\
\text { terranean }\end{array}$ & $\mathrm{Se}$ & $\begin{array}{l}\text { Powdered seeds are taken twice daily } \\
\text { to cure indigestion and other digestive } \\
\text { problems. }\end{array}$ \\
\hline $\begin{array}{l}\text { Jurinea macrocephala DC. } \\
\text { [Asteraceae] } \\
25504\end{array}$ & Guggal & $\begin{array}{l}\text { Kashmir to through- } \\
\text { out Himalaya }\end{array}$ & $\mathrm{R}$ & $\begin{array}{l}\text { Roots are used during religious cer- } \\
\text { emonies for incense. Root decoction } \\
\text { is given once per day to treat cold and } \\
\text { cough. }\end{array}$ \\
\hline $\begin{array}{l}\text { Leucas aspera (Willd.) } \\
\text { Link } \\
\text { [Lamiaceae] }\end{array}$ & Gophaa & $\begin{array}{l}\text { Kashmir to Sikkim, } \\
\text { Indo-China, Ma- } \\
\text { laysia }\end{array}$ & $\mathrm{F}$ & $\begin{array}{l}\text { The aroma of crushed flowers is in- } \\
\text { haled through the nostril for relief of } \\
\text { migraines. }\end{array}$ \\
\hline $\begin{array}{l}\text { Mentha longifolia (L.) L. } \\
\text { [Lamiaceae] } \\
25505\end{array}$ & Marhendri & $\begin{array}{l}\text { Indigenous to South } \\
\text { Africa }\end{array}$ & L & $\begin{array}{l}\text { Leaves are placed inside seed contain- } \\
\text { ers to deter insects and inside catteries } \\
\text { to protect them from ticks, mites, and } \\
\text { rat fleas. A paste is made from fresh } \\
\text { leaves and applied to burst boils for pus } \\
\text { removal. }\end{array}$ \\
\hline $\begin{array}{l}\text { Origanum vulgare L. } \\
\text { [Lamiaceae] } \\
26210\end{array}$ & Tulsi & $\begin{array}{l}\text { Macronesia, S Eu- } \\
\text { rope, Mediterra- } \\
\text { nean, SW and C } \\
\text { Asia, along the Hi- } \\
\text { malayan area to } \\
\text { China and Taiwan }\end{array}$ & L, St & $\begin{array}{l}\text { Dried leaves and shoots are boiled in } \\
\text { water, and the decoction is taken twice } \\
\text { daily to relieve cold and fever. The plant } \\
\text { is also used in many religious ceremo- } \\
\text { nies as a symbol of Vishnu. }\end{array}$ \\
\hline $\begin{array}{l}\text { Pinus roxburghii Sarg. } \\
\text { [Pinaceae] } \\
26209\end{array}$ & Chil & $\begin{array}{l}\text { Afghanistan, the } \\
\text { Himalaya from Chi- } \\
\text { tral east to Bhutan, } \\
\text { Sikkim }\end{array}$ & L & $\begin{array}{l}\text { Green needles are ground with water. } \\
\text { Extracted sap is taken once per day } \\
\text { to increase urine flow and treat kidney } \\
\text { stones. }\end{array}$ \\
\hline $\begin{array}{l}\text { Rheum australe D.Don } \\
\text { [Polygonaceae] } \\
25506\end{array}$ & Chukari & $\begin{array}{l}\text { Temperate and sub- } \\
\text { tropical Himalayas } \\
\text { from Kashmir to Sik- } \\
\text { kim, at } 2000 \text { to } 4500 \\
\mathrm{~m} \text { (Chauhan 1999) }\end{array}$ & $\mathrm{R}$ & $\begin{array}{l}\text { Roots are sun-dried and powdered, } \\
\text { then mixed with water to form a thick } \\
\text { paste which is applied to cuts and } \\
\text { wounds. }\end{array}$ \\
\hline $\begin{array}{l}\text { Rubia cordifolia L. } \\
\text { [Rubiaceae] } \\
25507\end{array}$ & Mishtu & $\begin{array}{l}\text { Throughout the hilly } \\
\text { districts of India } \\
\text { from NW Himalayas } \\
\text { eastward, ascend- } \\
\text { ing to } 8000 \mathrm{ft} \text {, and } \\
\text { southward to Cey- } \\
\text { lon }\end{array}$ & L, St & $\begin{array}{l}\text { Leaves and stems are used to scrub } \\
\text { the aching parts of skin so that the oint- } \\
\text { ment absorbs easily, relieving bone } \\
\text { aches. }\end{array}$ \\
\hline
\end{tabular}




\section{Rani \& Rana - Ethnobotanical Uses of Some Plants of Bhattiyat Block in District Chamba, Himachal Pradesh (Western Himalaya)}

Table 1. Continued.

\begin{tabular}{|c|c|c|c|c|}
\hline $\begin{array}{l}\text { Scientific name } \\
\text { [Family] } \\
\text { Acc. no. }\end{array}$ & $\begin{array}{l}\text { Local } \\
\text { name }\end{array}$ & Distribution & 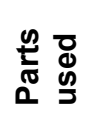 & Ethnobotanical use(s) \\
\hline $\begin{array}{l}\text { Sarcococca saligna Müll. } \\
\text { Arg. } \\
\text { [Buxaceae] } \\
25508\end{array}$ & Diyund & $\begin{array}{l}\text { Throughout the Hi- } \\
\text { malayas from Af- } \\
\text { ghanistan to W Nepal }\end{array}$ & $\mathrm{L}, \mathrm{St}$ & $\begin{array}{l}\text { Leaves are ground and the paste ap- } \\
\text { plied on burns as a coolant for quick } \\
\text { relief. }\end{array}$ \\
\hline $\begin{array}{l}\text { Saussurea costus (Falc.) } \\
\text { Lipsch. } \\
\text { [Asteraceae] } \\
25509\end{array}$ & Kuth & $\begin{array}{l}\text { Native to Himalayas } \\
\text { at 2500-3000 m (Sa- } \\
\text { mant et al. 1998) and } \\
\text { higher elevations of } \\
\text { Jammu, Kashmir, and } \\
\text { Himachal Pradesh } \\
\text { (Aswal \& Mehrotra } \\
\text { 1994) }\end{array}$ & $\mathrm{R}$ & $\begin{array}{l}\text { Dried roots are ground to powder and } \\
\text { taken orally to treat colds and joint pain. }\end{array}$ \\
\hline $\begin{array}{l}\text { Syzygium aromaticum (L.) } \\
\text { Merr. \& L.M.Perry } \\
\text { [Myrtaceae] }\end{array}$ & Laung & Native to Himalayas & $\mathrm{Bu}$ & $\begin{array}{l}\text { Powdered buds mixed with milk are ap- } \\
\text { plied to wounds and for toothaches. }\end{array}$ \\
\hline $\begin{array}{l}\text { Viola canescens Wall. } \\
\text { [Violaceae] } \\
25510\end{array}$ & Vanksha & $\begin{array}{l}\text { Himalayas at } 1500- \\
2400 \text { m, from Kash- } \\
\text { mir to NE India }\end{array}$ & $\mathrm{F}$ & $\begin{array}{l}\text { A decoction is prepared by boiling flow- } \\
\text { ers along with dalchini, mithisaunf, } \\
\text { and laung and taken orally to relieve } \\
\text { cold and cough. Flowers are also add- } \\
\text { ed in tea preparation. }\end{array}$ \\
\hline
\end{tabular}

list of medicinal plants prioritized for Western Himalaya and figuring among the 59 medicinal plants prioritized for conservation due to high extinction threat (Sastry \& Chatterjee 2000). The species is a major ingredient of the commercial drug available under the name gaozaban, which has antibacterial, antifungal, anti-inflammatory, and wound-healing properties (Kirtikar \& Basu 1984). In Kashmir Himalaya, the rhizome is used against cold, cough, fever, and as a blood purifier (Malik et al. 2011). Local peoples of Uttarakhand use it as hair tonic and antiseptic (Semwal et al. 2010). In District Chamba, it is also used against hair problems, which is reported here for the first time.

Sarcococca saligna Müll.Arg. was reported here as a burn treatment. Its antibacterial activity against several human pathogenic bacteria has been reported by Rahman et al. (1998). Rheum australe D.Don. is also useful against skin wounds, and its ethnomedicinal uses have been recorded from China, India, Nepal, and Pakistan for 57 different types of ailments, including ailments related to the circulatory, digestive, endocrine, respiratory, and skeletal systems as well as for infectious diseases in other parts of the world (Rokaya et al. 2012).

Two Asteraceae species were reported by informants as ethnobotanically useful: Jurinea macrocephala DC. and Saussurea costus (Falc.) Lipsch. Commonly, J. macro- cephala roots are used as a stimulant and given for colic or fever after child birth (Khare 2007). It is also used in Lahul \& Spiti districts during religious rituals called havan (Srivastava et al. 1992), similar to its use in this study as ceremonial incense. Saussurea costus was used here for colds and joint pain but is a well-known and important medicinal plant used in several indigenous systems of medicine for the treatment of asthma, inflammatory diseases, ulcers, and stomach problems (Pandey et al. 2007).

Two species from the mint family (Lamiaceae) were mentioned by informants. Mentha longifolia (L.) L. is commonly used as an antioxidant (Nickavar et al. 2008), antimicrobial (Al-Bayati 2009), and a hepatoprotective (Mimica-Dukic et al. 1999). Local vaidyas of Uttarakhand use leaves of $M$. longifolia to treat dehydration, vomiting, and liver diseases (Semwal et al. 2010). Oregano (Origanum vulgare L.) is widely used in agriculture and cosmetic industries as a culinary herb, a flavoring substance of food products and alcoholic beverages, and a perfume for its spicy fragrance (Aligiannis et al. 2001). Its spasmodic, antimicrobial, expectorant, carminative, and aromatic properties make it a traditional pharmaceutical remedy to treat various ailments such as whooping and convulsive coughs, digestive disorders, and menstrual problems (Aligiannis et al. 2001). 
Both Clematis barbellata Edgew. and M. Iongifolia (L.) L. were listed as useful against pimples and boils. In other parts of Himachal Pradesh, C. barbellata is used against itching and skin diseases (Rana \& Samant 2011). Clematis barbellata is additionally commonly used against diabetes.

In many parts of Himachal Pradesh and Pakistan, Viola canescens Wall. is used against cold and cough (Abbasi et al. 2010, Haq et al. 2011), matching what was reported by informants within Bhattiyat block.

Rubia cordifolia L. is reported here as being used against bone aches and skin itches and as an antiseptic for wounds. It has also been used in folk medicine against cancers, ulcers, swellings, and eczema (Karodi et al. 2009).

While Pinus roxburghii Sarg. was reported by informants as useful for kidney ailments, the essential oil (pine oil) is commonly used as an antiseptic, expectorant, carminative, and stimulant (Uniyal et al. 2006). From eastern Himalayan region, the seeds of $P$. roxbughii are used to treat indigestion (Kala 2005).

Reported here as useful against heavy sneezing and for making ceremonial wedding gates, Bergenia pacumbis (Buch.-Ham. ex D.Don) C.Y.Wu \& J.T.Pan is a well known Indian drug referred to as pashanbheda in Ayurveda. It is a key tonic for urinary complaints, kidney stones, colds, hemorrhagic disease, stomach distension, and epilepsy (Ruby et al. 2012). The root is used as a tonic, antidiabetic, antiscorbutic, cardiotonic, antidote to poison, and a treatment for conjunctivitis, fever, diarrhea, and cough (Kirtikar \& Basu 1983). An ethnobotanical study of Upper Siran Valley in Pakistan showed that $B$. ligulata was used there as a diuretic (Harsoliya et al. 2011). It has also been shown to be hepatoprotective, and alcoholic extracts of $B$. ligulata showed anticancer, antiprotozoal, diuretic, cardiovascular, antiscorbutic, and antilithiatic properties (Garodia et al. 2007).

\section{Conclusion}

Only 22 plant species were identified as medicinal in this part of the Himalayas. In a global or regional sense this is a surprisingly small number but reflects the state of traditional knowledge among the people interviewed. We expect that further interviews would reveal more plants and details of use since much higher numbers are found in other districts of this region.

\section{Acknowledgments}

We greatly thank the farming communities of the region for their willingness and sharing empirical knowledge and experiences on wild useful plants. We also thank NBPGR (National Bureau of Plant Genetic Resource) and NAIP (National Agricultural Innovation Project), New Delhi, for providing financial assistance.

\section{Literature Cited}

Abbasi, A.M., M.A. Khan, M. Ahmed \& M. Zafar. 2010. Herbal medicines used to cure various ailments by the inhabitants of Abbottabad district, North West Frontier Province, Pakistan. Indian Journal of Traditional Knowledge 9(1):175-183.

Ahsan, R., M. Islam, E. Haque \& A. Mossaddik. 2009. In vitro antibacterial screening and toxicological study of some different medicinal plants. World Journal of Agricultural Sciences 5:617-621.

Al-Bayati, F.A. 2009. Isolation and identification of antimicrobial compound from Mentha longifolia L. leaves grow wild in Iraq. Annals of Clinical Microbiology and Antimicrobials 8:20. $\underline{\mathrm{dx} . \text { doi.org/10.1186/1476-0711-8-20 }}$

Aligiannis, N., E. Kalpoutzakis, S. Mitaku \& I.B. Chinou. 2001. Composition and antimicrobial activity of the essential oils of two Origanum species. Journal of Agricultural and Food Chemistry 49:4168-4170. dx.doi.org/10.1021/ if001494m

Ambasta, S.P. 2004. The Useful Plants of India. 4th edition. National Institute of Science Communication, New Delhi, India.

Aswal, B.S. \& B.N. Mehrotra. 1994. Flora of Lahaul-Spiti: A cold desert in North Western Himalaya. Bishen Singh Mahendra Pal Singh, Dehra Dun, Uttarakhand, India.

Chauhan, N.S. 1999. Medicinal and Aromatic Plants of Himachal Pradesh. Indus Publishing Company, New Delhi, Delhi, India.

Chowdhery, H.J. \& B.M. Wadhwa. 1984. Flora of Himachal Pradesh: Analysis. Volumes 1-2. Botanical Survey of India, Calcutta, India.

Dhaliwal, D.S. \& M. Sharma. 1999. Flora of Kullu District (Himachal Pradesh). Bishen Singh Mahendra Pal Singh, Dehra Dun, India.

Dutt, B., S.S. Sharma, K.R. Sharma, A. Gupta \& H. Singh. 2011. Ethnobotanical survey of plants used by Gaddi tribe of Bharmour area in Himachal Pradesh. ENVIS Bulletin: Himalayan Ecology 19:22-27. http://gbpihedenvis.nic.in/ HTML/Vol\%2019/Vol\%2019.pdf

Garodia, P., H. Ichikawa, N. Malani, G. Sethi \& B.B. Aggarwal. 2007. From ancient medicine to modern medi- 


\section{Rani \& Rana - Ethnobotanical Uses of Some Plants of Bhattiyat Block in District Chamba, Himachal Pradesh (Western Himalaya)}

cine: Ayurvedic concepts of health and their role in inflammation and cancer. Journal of the Society for Integrative Oncology 5(1):25-37.

Gohil, K.J. \& J.A. Patel. 2010. A review on Bacopa monniera: Current research and future prospects. International Journal of Green Pharmacy 4(1):1-9. www.greenpharmacy.info/text.asp?2010/4/1/1/62156

Haq, F., H. Ahmad \& M. Alam. 2011. Traditional uses of medicinal plants of Nandiar Khuwarr catchment (District Battagram), Pakistan. Journal of Medicinal Plants Research 5(1):39-48. www.academicjournals.org/article/article1380532251_Haq\%20et\%20al.pdf

Harsoliya, M.S., J.K. Pathan, N. Khan, D. Bhatt \& U.M. Patel. 2011. Effect of ethanolic extracts of Bergenia ligulata, Nigella sativa and combination on calcium oxalate urolithiasis in rats. International Journal of Drug Formulation \& Research 2(2):268-280. www.ordonearresearchlibrary. org/Data/pdfs/IJDFR93.pdf

Kala, C.P. 2005. Ethnomedicinal botany of the Apatani in the Eastern Himalayan region of India. Journal of Ethnobiology and Ethnomedicine 1:11. dx.doi.org/ 10.1186/17464269-1-11

Karodi, R., M. Jadhav, R. Rub \& A. Bafna. 2009. Evaluation of the wound healing activity of a crude extract of Rubia cordifolia L. (Indian madder) in mice. International Journal of Applied Research in Natural Products 2(2):1218. www.ijarnp.org/index.php/ijarnp/article/view/54/55

Kaur, H. \& M. Sharma. 2004. Flora of Sirmaur. Bishen Singh Mahendra Pal Singh, Dehra Dun, India.

Khare, C.P. 2007. Indian Medicinal Plants: An illustrated dictionary. Springer-Verlag, Berlin/Heidelberg, Germany.

Kirtikar, K.R. \& B.D. Basu. 1983. Indian Medicinal Plants. Volume 3. Second edition. Lalit Mohan Basu Publication, Allahabad, India.

Kirtikar, K.R. \& B.D. Basu. 1984. Indian Medicinal Plants. Volume 3. Bishen Singh Mahendra Pal Singh, Dehradun, India.

Malik, H.A., A.A. Khuroo, G.H. Dar \& Z.S. Khan. 2011. Ethnomedicinal uses of some plants in the Kashmir Himalaya. Indian Journal of Traditional Knowledge 10(2):362366.

Martin, G.J. 1995. Ethnobotany: A methods manual. Chapman and Hall, London, U.K.

Mimica-Dukic, N., M. Popovic, V. Jakovljevic, A. Szabo \& O. Gašic. 1999. Pharmacological studies of Mentha longifolia phenolic extracts. II. Hepatoprotective activity. Phar- maceutical Biology 37(3):221-224. dx.doi.org/10.1076/ phbi.37.3.221.6306

Nickavar, B., A. Alinaghi \& V. Kamalinejad. 2008. Evaluation of the antioxidant properties of five Mentha species. Iranian Journal of Pharmaceutical Research 7(3):203209.

Pandey, G. 1988. Dravyaguna Vijnana. Materia medica: Vegetable drugs. Volume III. Krishnadas Academy, Varanasi, Uttar Pradesh, India.

Pandey, M.M., S. Rastogi \& A.K.S. Rawat. 2007. Saussurea costus: Botanical, chemical and pharmacological review of an ayurvedic medicinal plant. Journal of Ethnopharmacology 110(3):379-390. dx.doi.org/10.1016/j. iep.2006.12.033

Rahman, A., S. Anjum, A. Farooq, M.R. Khan \& M.I. Choudhary. 1998. Phytochemical studies on steroidal alkaloids of Sarcococca saligna. Natural Product Letters 11(4):297-304. dx.doi.org/10.1080/10575639808044963

Rana, M.S. \& S.S. Samant. 2011. Diversity, indigenous uses and conservation status of medicinal plants in Manali wildlife sanctuary, North western Himalaya. Indian Journal of Traditional Knowledge 10(3):439-459.

Reyes-Garcia, V., V. Vadez, E. Byron, L. Apaza, W.R. Leonard, E. Perez \& D. Wilkie. 2005. Market economy and the loss of folk knowledge of plant uses: Estimates from the Tsimane' of the Bolivian Amazon. Current Anthropology 46(4):651-656. www.jstor.org/stable/10.1086/432777

Rokaya, M.B., Z. Münzbergová, B. Timsina \& K.R. Bhattarai. 2012. Rheum australe D. Don: A review of its botany, ethnobotany, phytochemistry and pharmacology. Journal of Ethnopharmacology 141(3):761-774. dx.doi. org/10.1016/j.jep.2012.03.048

Ruby, K., R. Chauhan, S. Sharma \& J. Dwivedi. 2012. Polypharmacological activities of Bergenia species. International Journal of Pharmaceutical Sciences Review and Research 13(1):100-110. http://globalresearchonline.net/ journalcontents/v13-1/018.pdf

Samant, S.S., U. Dhar \& L.M.S. Palni. 1998. Medicinal Plants of Indian Himalaya: Diversity, distribution, potential value. HIMAVIKAS Publication No. 13. Gyananodaya Prakashan, Nainital, India.

Sastry, A.R.K. \& S. Chatterjee. 2000. Prioritization of medicinal plants of India. Pp. 467-473 in Setting Biodiversity Conservation Priorities for India. Volume 2. Edited by S. Singh, A.R.K. Sastry, R. Mehta \& V. Uppal. World Wildlife Federation-India, New Delhi, Delhi, India. 
Semwal, D.P., P.P. Saradhi, C.P. Kala \& B.S. Sajwan. 2010. Medicinal plants used by local vaidyas in Ukhimath block, Uttarakhand. Indian Journal of Traditional Knowledge 9(3):480-485.

Sharma, M. \& H. Singh. 1990. Observations on floristic composition of Chamba District, Himachal Pradesh. New Botanist 17:273-281.

Sharma, M. \& H. Singh. 1997. Observations on the herbaceous vegetation of Chamba District. Pp. 147-153 in Current Researches in Plant Sciences. Edited by T.A. Sarma, S.S. Saini, M.L. Trivedi \& M. Sharma. Bishen Singh Mahendra Pal Singh, Dehradun, India.

Singh, H. \& M. Sharma. 2006. Flora of Chamba District. Bishen Singh Mahendra Pal Singh, Dehradun, India.

Singh, V. \& H.S. Banyal. 2012. Diversity and ecology of mammals in Kalatop-Khajjiar wildlife sanctuary, District Chamba (Himachal Pradesh), India. International Journal of Science and Nature 3(1):125-128. www.sci-
enceandnature.org/IJSN Vol3\%281\%29M2012/IJSNVOL3\%281\%29-23.pdf

Srivastava, T.N., B.K. Kapahi \& Y.K. Sarin. 1992. Ethnobotanical studies in Lahul and Spiti, Himachal Pradesh. Ancient Science of Life 11(3\&4):126-130.

The Plant List. 2013. Version 1.1. www.theplantlist.org. Accessed March 2014.

Thomson, M. \& M. Ali. 2003. Garlic [Allium sativum]: A review of its potential use as an anti-cancer agent. Current Cancer Drug Targets 3(1):67-81. dx.doi. org/10.2174/1568009033333736

Tropicos.org. 2014. Missouri Botanical Garden. www.tropicos.org. Accessed March 2014.

Uniyal, S.K., K.N. Singh, P. Jamwal \& L. Brij. 2006. Traditional use of medicinal plants among the tribal communities of Chhota Bhangal, Western Himalaya. Journal of Ethnobiology and Ethnomedicine 2:14. dx.doi. org/10.1186/1746-4269-2-14 